\title{
Die Kaapkolonie in die geskiedskrywing en in die letterkunde
}

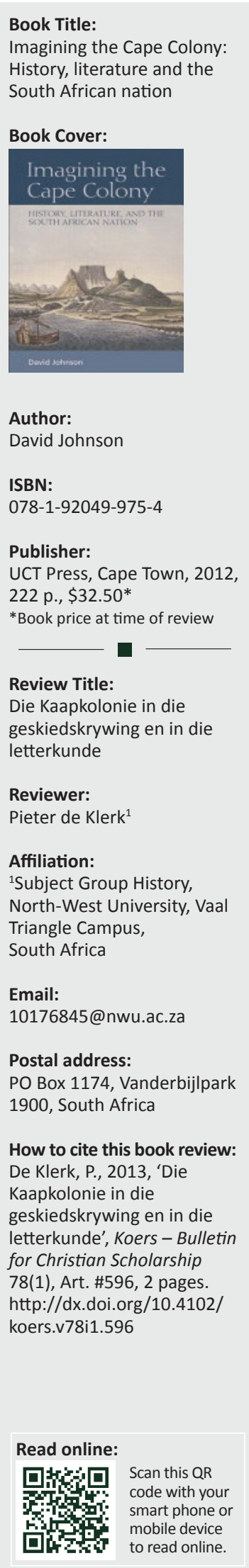

In hierdie boek word die interpretasies van kontemporêre en latere skrywers ten opsigte van onderwerpe uit die Kaapse koloniale geskiedenis in sewe afsonderlike hoofstukke bespreek. Die volgende onderwerpe word in die verskillende hoofstukke hanteer:

- die neerlaag en dood van Francisco d'Almeida na 'n botsing met die Khoikhoi aan die Kaap in 1510, soos weergegee in vroeë Portugese en latere Britse en Suid-Afrikaanse geskrifte en toesprake

- beskrywings van die Kaapse Khoikhoi deur sewentiende- en agtiende-eeuse Franse skrywers

- sewentiende- en agtiende-eeuse Britse geskrifte rakende die ekonomiese lewensvatbaarheid en bestuur van die Kaapkolonie

- agtiende- en negentiende-eeuse Amerikaanse tekste waarin onder meer die moontlikheid bespreek word dat die VSA die Kaap as kolonie oorneem

- vroeë en latere geskrifte oor die verskynsel van republikanisme onder die Nederlandse koloniste aan die Kaap gedurende die laat agtiende eeu

- tekste waarin slawerny aan die Kaap bespreek en uitgebeeld word vanaf die agtiende eeu tot vandag

- vroeë en latere geskrifte oor die geskiedenis van die Griekwas.

In al die hoofstukke kom Johnson se uitgebreide kennis van veral Europese en Suid-Afrikaanse historici en letterkundiges se werke van die afgelope eeue na vore. Die waarde van die boek lê waarskynlik hoofsaaklik daarin dat dit 'n oorsig bied van die geskrifte van 'n verskeidenheid outeurs, insluitende reisigers, historici, filosowe, politici, romanskrywers en digters, ten opsigte van 'n aantal belangrike aspekte van die Kaapse koloniale geskiedenis.

Johnson het verskeie oogmerke met hierdie werk. Hy bespreek die geskrifte met betrekking tot huidige debatte binne die vakgebied van postkoloniale studie oor byvoorbeeld nasionalisme onder koloniale setlaars, weerstand teen kolonialisme en die invloed van agtiende-eeuse werke oor die koloniale geskiedenis op huidige neo-koloniale politieke praktyke. Hy wil ook nagaan hoe resente pogings om 'n Suid-Afrikaanse nasie in die era na apartheid te 'verbeel', met besondere verwysing na toesprake van Thabo Mbeki, tot die herinterpretasie kan lei van bepaalde aspekte van die geskiedenis van die Kaapkolonie. Hierdie doelstellings hou verband met verskillende teorieë wat Johnson as uitgangspunte aanvaar soos dié van Benedict Anderson, naamlik dat volke of nasies as 'verbeelde gemeenskappe' (imagined communities) beskou kan word. Sy interpretasies word in sekere opsigte vanuit 'n voorafbepaalde raamwerk gedoen wat meebring dat skrywers soms in kategorieë geplaas word waarin hulle nie heeltemal pas nie. In die hoofstuk oor die opstande in Graaff-Reinet en Swellendam (1795-1799) argumenteer hy byvoorbeeld dat die groot aantal skrywers wat gedurende die afgelope twee eeue oor die motiewe van die opstandelinge geskryf het, binne drie mites ten opsigte van die Afrikaner se nasionale identiteit geplaas kan word. Hierdie mites is naamlik dat die Afrikaners agterlike boere was, dat die Afrikaner God se uitverkore volk is en dat die Afrikaner 'n Prometheusfiguur is wat hom suksesvol teen verdrukking en uitbuiting verset het en nuwe uitdagings die hoof probeer bied het. 'n Onakkurate stereotipering van Afrikanernasionalisme word versterk deur die plasings van skrywersinterpretasies, beïnvloed deur Afrikanernasionalisme, onder die opskrif 'God se uitverkore volk'. Afrikaanse nasionalistiese interpretasies asook dié van Engelstalige skrywers soos G.M. Theal word egter by hierdie groep ingedeel. Deur die interpretasies in drie kategorieë in te deel, kom die verskillende aspekte van elke interpretasie nie tot hulle reg nie. Hierdeur word 'n oorvereenvoudigde beeld gebied van 'n verskeidenheid beskouings wat sedert die laat agtiende eeu ten opsigte van die Afrikaner bestaan het. In sommige van die ander hoofstukke kom soortgelyke probleme voor.

Alhoewel Johnson nie baie uitgebreide aandag aan eietydse pogings gee om die Suid-Afrikaanse geskiedenis ter wille van nasiebou te herinterpreteer nie, is sy kommentaar op Mbeki se toesprake

Copyright: () 2013. The Authors. Licensee: AOSIS OpenJournals. This work is licensed under the Creative Commons Attribution License. 
beslis insiggewend. Hy toon byvoorbeeld aan dat Mbeki die oorwinning van die Khoikhoi oor D'Almeida beskou as deel van die lang stryd van die Afrikane teen koloniale oorheersing. Hy het, soos ook ander politici, dikwels aanhalings van antikapitalistiese en anti-kolonialistiese skrywers in sy toesprake gebruik om daardeur juis 'n ekonomiese beleid, gegrond op vryemarkbeginsels, te regverdig. Ander aspekte van die Kaapse koloniale geskiedenis soos die stelsel van slawerny, is ook deur Mbeki gebruik om binne die konteks van die algemene geskiedenis van slawerny, bepaalde stellings oor die huidige posisie van Afrikane in die wêreldekonomie te maak.

Of 'n mens met Johnson se uitgangspunte saamstem of nie, sy werk lewer 'n belangrike bydrae tot die historiese en letterkundige wetenskappe, in die besonder tot die vakgebiede van historiografie en postkoloniale studies. Vir almal wat gemoeid is met navorsing en onderrig op hierdie terreine en ook vir diegene met 'n belangstelling in die geskiedenis van die Kaapkolonie, sal dit die moeite loon om hulle van die inhoud van hierdie werk te vergewis. 